\title{
Preserved C-peptide levels in overweight or obese compared with underweight children upon diagnosis of type 1 diabetes mellitus
}

Hyeoh Won Yu, MD, Yun Jeong Lee, MD, Won Im Cho, MD, Young Ah Lee, MD, PhD, Choong Ho Shin, MD, PhD, Sei Won Yang, MD, PhD

Department of Pediatrics, Seoul National University Children's Hospital, Seoul National University College of Medicine, Seoul, Korea
Received: 4 June, 2015 Revised: 18 June, 2015 Accepted: 19 June, 2015

\footnotetext{
Address for correspondence: Young Ah Lee, MD, PhD Department of Pediatrics, Seoul National University Children's Hospital, Seoul National University College of Medicine, 101 Daehak-ro, Jongno-gu, Seoul 110-744, Korea Tel: $+82-2-2072-2308$ Fax: $+82-2-743-3455$ E-mail:nina337@snu.ac.kr
}

Purpose: We hypothesized that overweight or obese children might develop type 1 diabetes mellitus (T1DM) early despite residual beta-cell function. Factors independently associated with preservation of C-peptide level were analyzed.

Methods: We retrospectively reviewed the medical data of 135 children aged 2.1-16.5 years with autoimmune T1DM. Body mass index (BMI), pubertal stage, and glycosylated hemoglobin ( $\mathrm{HbA} 1 \mathrm{c})$ and C-peptide levels were evaluated. Patients were assigned to underweight (22.2\%), normal weight (63.7\%), and overweight or obese (14.1\%) groups according to their BMI.

Results: Preservation of serum C-peptide levels ( $\geq 0.6 \mathrm{ng} / \mathrm{mL}$ ) was found in $43.0 \%$ of subjects. With increasing BMl, the proportions of children with preserved C-peptide levels increased from $33.3 \%$ to $41.9 \%$ to $63.2 \%$, with marginal significance $(P=0.051)$. Interaction analysis indicated no effect of BMI score on age at onset associated with serum C-peptide levels. The lower the C-peptide level, the younger the age of onset $(P<0.001)$, after adjustment for BMI $z$-score and $\mathrm{HbA} 1 \mathrm{c}$ level. However, no significant relationship between BMI $z$-score or category and onset age was evident. Upon multivariate-adjusted modeling, the odds that the C-peptide level was preserved increased by 1.2 fold $(P=0.001)$ per year of life, by 3.1 folds $(P=0.015)$ in children presenting without (compared to with) ketoacidosis, and by 5.0 folds $(P=0.042)$ in overweight or obese (compared to underweight) children.

Conclusion: Overweight or obese children had slightly more residual beta-cell function than did underweight children. However, we found no evidence that obesity temporally accelerates T1DM presentation.

Keywords: Type 1 diabetes mellitus, C-peptide, Body mass index, Obesity, Age of onset

\section{Introduction}

Diabetes of type 1 or 2 develops when insulin requirements cannot be met due to functional loss of beta cells ${ }^{1)}$. Such loss in patients with type 1 diabetes mellitus (T1DM) is caused by autoimmune destruction, which can be accelerated by insulin resistance. The coexistence of autoimmunity and insulin resistance has led to the concepts of "double diabetes ${ }^{12)}$, "overload"3), or "latent autoimmune diabetes of adulthood (LADA)" ${ }^{n 4}$.

Although T1DM patients are generally thought to be completely insulin deficient, some patients exhibit residual beta-cell function. The extent of such function and the rate of betacell loss vary among patients. Excess weight may accelerate T1DM onset and subsequent betacell loss. Thus, it is possible that excess weight might hasten the manifestations of pre-existing autoimmune beta-cell damage, ${ }^{5,6)}$.

We hypothesized that overweight or obese patients might develop T1DM earlier than others, 
despite the existence of residual beta-cell function. We explored whether C-peptide levels were more frequently preserved in overweight or obese T1DM patients, and if T1DM developed at a younger age in such patients. Factors independently associated with preservation of $\mathrm{C}$-peptide levels were determined.

\section{Materials and methods}

\section{Subjects}

This study was approved by the Seoul National University Hospital Institutional Review Board (IRB No. 1502-078-649). The medical charts of 253 patients with T1DM followed-up at Seoul National University Children's Hospital between January 2005 and July 2014 were reviewed retrospectively. Insulindependent children with autoimmune T1DM, positive for one or more of three autoantibodies including anti-glutamic acid decarboxylase (GAD) antibody, islet-cell antibody, and insulin antibody, were included initially.

All insulin-dependent patients followed-up for $\geq 2$ years were included. Among patients who were followed up for $<2$ years, those positive for two or three autoantibodies who were diagnosed before puberty and/or had low C-peptide levels were also included. In total, 118 patients were excluded because of a negative autoantibody status $(\mathrm{n}=56)$, missing $\mathrm{C}$-peptide values and/or body mass index (BMI) data at diagnosis $(n=41)$; it was not possible to categorize overweight or obesity in children $<2$ years of age due to a lack of reference data $(n=15)$, and in some patients with preserved C-peptide levels and short follow-up durations $(n=6)$. Finally, 135 insulin-dependent children aged 2-18 years with autoimmune T1DM were included in the study.

\section{Clinical and biochemical data}

Age, sex, birth weight, height, pubertal staging, and the presence of diabetic ketoacidosis (DKA) at the time of T1DM diagnosis were recorded. Weight at discharge or at the first visit to the outpatient clinic was used to calculate BMI after recovery from hyperglycemia and/or DKA. BMI was calculated as weight (in kilograms) divided by height squared (in meters). Using the 2007 Korean National Growth Chart ${ }^{7}$, patients were categorized as underweight $(<15 \text { th percentile })^{8)}$, normal weight (15th to $<85$ th percentiles), overweight (85th to $<95$ th percentiles), or obese ( $\geq 95$ th percentile). Serum $\mathrm{pH}$, concentrations of glucose, glycosylated hemoglobin (HbAlc), C-peptide, bicarbonate, anti-GAD antibody, islet-cell antibody, and insulin-antibody at diagnosis, and $\mathrm{HbAlc}$ levels during follow-up were measured. C-peptide levels are a clinically validated, well-known marker of beta-cell function" ${ }^{9}$. As C-peptide was measured randomly regarding meal consumption at diagnosis of T1DM, it was considered stimulated. The preservation of C-peptide, indicating residual beta-cell function, was defined as a stimulated C-peptide level $\geq 0.6 \mathrm{ng} / \mathrm{mL}^{10-13)}$.

\section{Statistical analysis}

All statistical analyses were conducted with IBM SPSS Statistics ver. 20.0 (IBM Co., Armonk, NY, USA). All continuous variables are described as the mean \pm standard deviation. Analysis of normality was firstly performed. Variables with a skewed distribution were log-transformed for further analysis. Student $t$ test and one-way analysis of variance were used to compare the mean values of continuous variables. The chi-square test and the chi-square test for trends were used to compare categorical variables between groups. Univariate and multivariate linear regression analyses were performed to identify determinants for age at diagnosis and serum C-peptide at diagnosis, respectively. Univariate and multivariate binary logistic regression analyses were undertaken to evaluate predictors for whether or not C-peptide levels were preserved $(\geq 0.6 \mathrm{ng} / \mathrm{mL}$ ). In all analysis, the statistical significance was defined as less than 0.05 of $P$-values.

\section{Results}

The clinical and biochemical characteristics of the 135 patients (57 males, 60 pubertal) are shown in Table 1. The mean age at

Table 1. The clinical and biochemical characteristics of underweight, normal weight, and overweight/obese children

\begin{tabular}{|c|c|c|c|c|c|}
\hline & All patients & Underweight & Normal weight & Overweight or obese & $P$-value \\
\hline No. of patients & $135(100)$ & $30(22.2)$ & $86(63.7)$ & $19(14.1)$ & \\
\hline Male sex & $57(42.2)$ & $13(43.3)$ & $39(45.3)$ & $5(26.3)$ & 0.329 \\
\hline Birth weight (kg) & $3.20 \pm 0.53$ & $3.18 \pm 0.43$ & $3.17 \pm 0.58$ & $3.44 \pm 0.37$ & 0.183 \\
\hline Age at diagnosis (yr) & $9.05 \pm 4.29$ & $9.48 \pm 4.75$ & $8.94 \pm 4.17$ & $8.86 \pm 4.25$ & 0.927 \\
\hline Pubertal onset of diabetes & $60(44.4)$ & $14(46.7)$ & $36(41.9)$ & $10(52.6)$ & 0.797 \\
\hline C-peptide (ng/mL) & $0.77 \pm 0.88$ & $0.63 \pm 0.80$ & $0.71 \pm 0.65$ & $1.26 \pm 1.56$ & 0.131 \\
\hline Preserved C-peptide & $58(43.0)$ & $10(33.3)$ & $36(41.9)$ & $12(63.2)$ & 0.051 \\
\hline Glucose (mg/dL) & $441.86 \pm 170.88$ & $473.93 \pm 178.43$ & $435.07 \pm 163.58$ & $419.29 \pm 191.75$ & 0.469 \\
\hline $\mathrm{HbA1c}(\%)$ & $12.06 \pm 2.24$ & $12.04 \pm 2.06$ & $12.20 \pm 2.31$ & $11.38 \pm 2.17$ & 0.402 \\
\hline Average of $\mathrm{HbA} 1 \mathrm{C}$ for 2 years (\%) & $8.57 \pm 1.50$ & $8.47 \pm 1.10$ & $8.56 \pm 1.45$ & $8.80 \pm 2.18$ & 0.900 \\
\hline Presentation without DKA at diagnosis ${ }^{\text {a) }}$ & $38(35.8)$ & $4(20.0)$ & $26(38.2)$ & $8(44.4)$ & 0.112 \\
\hline
\end{tabular}

Values are presented as number (\%) or mean \pm standard deviation.

$\mathrm{HbA1c}$, glycosylated hemoglobin; DKA, diabetic ketoacidosis.

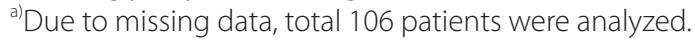


diagnosis was 9.1 years $(2.1-16.5$ years). The mean level of serum C-peptide was $0.77 \mathrm{ng} / \mathrm{mL}(0.05-6.8 \mathrm{ng} / \mathrm{mL})$. Of all patients, $43 \%$ had preserved C-peptide levels. The mean HbAlc level was $12.1 \%(6.3 \%-18.0 \%)$. Of all patients, $35.8 \%$ presented without DKA at diagnosis. According to BMI, 22.2\% of the children were underweight, $63.7 \%$ normal weight, and $14.1 \%$ overweight or obese (Table 1). As BMI category increased from underweight, to normal weight, to overweight or obese, the proportions of children with preserved C-peptide levels increased from 33.3\%, to $41.9 \%$, to $63.2 \%$, respectively, with marginal significance $(P=0.051)$ (Fig. 1A). No significant among-group differences in sex, age at diagnosis, HbAlc level, or presentation without DKA were evident (Table 1).

Patients with preserved C-peptide levels were older at onset (10.8 years vs. 7.7 years, $P<0.001$ ), more likely to be pubertal (63.8\% vs. $29.9 \%, P<0.001)$, and presented more frequently without DKA (51.2\% vs. $26.2 \%, P=0.009)$, compared with the non-preserved C-peptide group. No difference in either $\mathrm{HbAlc}$ level at diagnosis or the average $\mathrm{HbAlc}$ level during the 2-year follow-up was evident between the two groups (Table 2).

No interaction of serum C-peptide level with the effect of BMI $z$-score or category on age at diagnosis was noted. The lower the
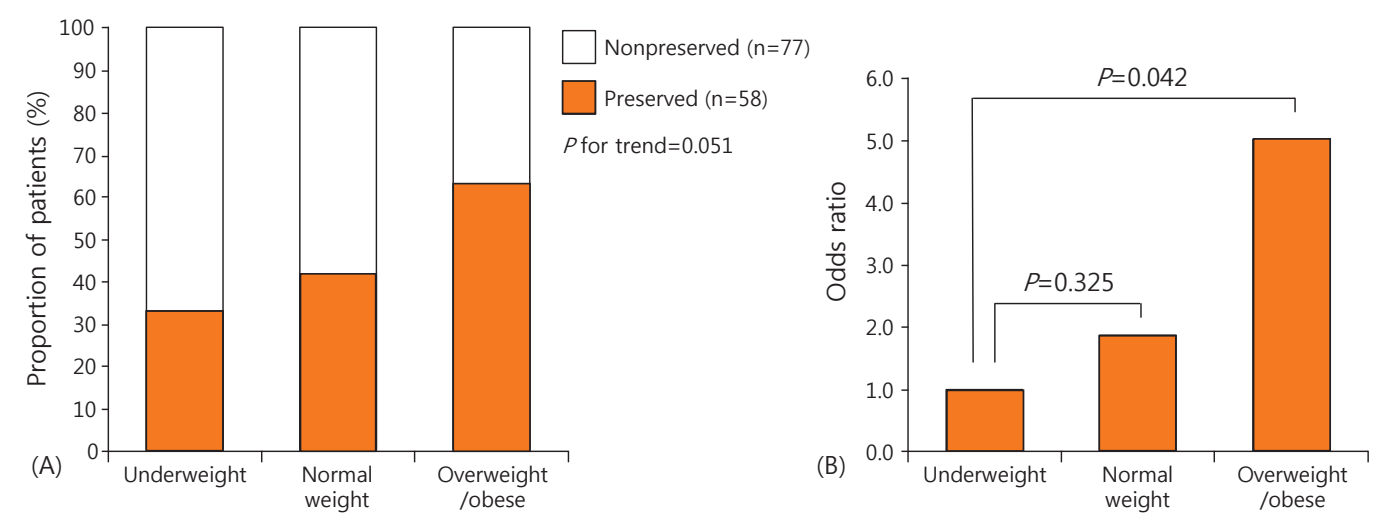

Fig. 1. The proportions of preserved C-peptide levels and the odds of such preservation by body mass index (BMI) category. (A) As $\mathrm{BMI}$ category increased from underweight, to normal weight, to overweight or obese, the proportions of children with preserved C-peptide levels increased from $33.3 \%$, to $41.9 \%$, to $63.2 \%$, respectively, with marginal significance $(P=0.051)$. (B) In the final multivariate logistic regression model, the odds of $\mathrm{C}$-peptide preservation increased 1.9 fold $(P=0.325)$ in normal weight and 5.0 folds $(P=0.042)$ in overweight or obese children compared with underweight children.

Table 2. The clinical and biochemical characteristics of patients with versus without preserved C-peptide levels

\begin{tabular}{|c|c|c|c|}
\hline & Nonpreserved & Preserved & $P$-value \\
\hline No. of patients & $77(57.0)$ & $58(43.0)$ & \\
\hline Male sex & $32(41.6)$ & $25(43.1)$ & 0.857 \\
\hline Birth weight (kg) & $3.20 \pm 0.46$ & $3.20 \pm 0.57$ & 0.879 \\
\hline Age at diagnosis (yr) & $7.69 \pm 4.16$ & $10.84 \pm 3.79$ & $<0.001$ \\
\hline Pubertal onset of diabetes & $23(29.9)$ & $37(63.8)$ & $<0.001$ \\
\hline Body mass index z-score & $-0.236 \pm 1.08$ & $0.033 \pm 1.12$ & 0.162 \\
\hline C-peptide (ng/mL) & $0.29 \pm 0.15$ & $1.42 \pm 1.03$ & $<0.001$ \\
\hline Glucose (mg/dL) & $467.89 \pm 173.71$ & $409.20 \pm 163.10$ & 0.054 \\
\hline $\operatorname{HbA1c}(\%)$ & $12.22 \pm 1.95$ & $11.84 \pm 2.60$ & 0.367 \\
\hline Average of $\mathrm{HbA} 1 \mathrm{C}$ for 2 years (\%) & $8.65 \pm 1.47$ & $8.46 \pm 1.54$ & 0.384 \\
\hline Presentation without DKA at diagnosis ${ }^{\text {a) }}$ & $17(26.2)$ & $21(51.2)$ & 0.009 \\
\hline
\end{tabular}

Values are presented as number (\%) or mean \pm standard deviation.

HbA1c, glycosylated hemoglobin; DKA, diabetic ketoacidosis.

${ }^{a)}$ Due to missing data, total 106 patients were analyzed.

Table 3. Factors associated with age at diagnosis of type 1 diabetes

\begin{tabular}{|c|c|c|c|c|}
\hline \multirow{2}{*}{ Factor } & \multicolumn{2}{|c|}{ Unadjusted } & \multicolumn{2}{|c|}{ Adjusted } \\
\hline & $\beta(95 \% \mathrm{Cl})$ & $P$-value & $\beta(95 \% \mathrm{Cl})$ & $P$-value \\
\hline Body mass index $z$-score & $-0.008(-0.05$ to 0.03$)$ & 0.703 & $-0.024(-0.06$ to 0.01$)$ & 0.211 \\
\hline C-peptide & $0.083(0.04-0.13)$ & 0.001 & $0.105(0.06-0.15)$ & $<0.001$ \\
\hline $\mathrm{HbA} 1 \mathrm{c}$ & $0.027(0.01-0.05)$ & 0.008 & $0.035(0.02-0.05)$ & $<0.001$ \\
\hline
\end{tabular}

$\mathrm{Cl}$, Confidence interval; HbA1c, glycosylated hemoglobin. 
C-peptide level, the younger the age of onset $(P<0.001)$ after adjustment for BMI $z$-score and HbAlc level. However, any inverse relationship between BMI $z$-score or category and age at onset was not statistically significant, regardless of whether the serum C-peptide level was adjusted (Table 3).

Upon univariate linear regression analysis, older age at onset $(P<0.001)$, initial presentation without DKA $(P=0.006)$, overweight or obese status ( $P=0.044$ vs. underweight status), and pubertal onset of diabetes $(P<0.001)$ were positively associated with serum C-peptide levels. Upon multivariate linear regression analysis, serum $\mathrm{C}$-peptide levels were significantly higher in children of older age at onset $(P=0.001)$, who presented without rather than with DKA $(P=0.013)$, and who were overweight or obese compared with underweight $(P=0.022)$ (Table 4$)$.

Upon univariate logistic regression analysis, patients with preserved C-peptide levels showed older age at onset (odds ratio $[\mathrm{OR}], 1.2 ; P<0.001)$, initial presentation without DKA (OR, 3.0; $P=0.01$ ), overweight or obese status (OR, 3.4; $P=0.045$ vs. underweight status), and pubertal onset of diabetes (OR, 4.1; $P<0.001)$ compared with those without. In the final multivariate logistic regression model, the odds of C-peptide preservation increased 1.2 fold (95\% confidence interval [CI], 1.1-1.4; $P=0.001)$ with each year of age; 3.1 folds (95\% CI, 1.2-7.8; $P=0.015)$ in children who presented without rather than with DKA; and 5.0 folds (95\% CI, 1.1-23.7; $P=0.042$ ) (Fig. 1B) in overweight or obese children compared with underweight children (Table 5).

\section{Discussion}

Of 135 pediatric patients with autoimmune T1DM, $14.4 \%$ were overweight or obese. A younger age of onset was significantly associated with lower C-peptide levels, but neither overweight nor obese patients exhibited more rapid onset. An older age of onset, initial presentation without DKA, and overweight or obese status (compared with underweight) were significantly associated with preservation of C-peptide levels at the time of T1DM diagnosis.

Children who were overweight or obese at diagnosis exhibited slightly more residual beta-cell function. Although the significance was marginal, the proportions of patients with preserved C-peptide levels increased as BMI increased from underweight, to normal, to overweight or obese. In a multivariate-adjusted model, C-peptide preservation was more frequently evident in overweight or obese children compared with underweight children at the time of T1DM diagnosis, consistent with the data of previous studies ${ }^{13-15}$. Although overweight or obese children had slightly more residual beta-cell function, such patients developed hyperglycemia and diabetes triggered by the glucotoxicity and lipotoxicity

Table 4. Factors associated with serum C-peptide levels at diagnosis

\begin{tabular}{|c|c|c|c|c|}
\hline \multirow{2}{*}{ Factor } & \multicolumn{2}{|l|}{ Unadjusted } & \multicolumn{2}{|c|}{ Adjusted } \\
\hline & $\beta(95 \% \mathrm{Cl})$ & $P$-value & $\beta(95 \% \mathrm{Cl})$ & $P$-value \\
\hline Age at diagnosis (yr) & $0.032(0.02-0.05)$ & $<0.001$ & $0.029(0.01-0.05)$ & 0.001 \\
\hline Pubertal onset of diabetes (vs. prepubertal) & $0.258(0.12-0.40)$ & $<0.001$ & - & - \\
\hline Presentation without DKA (vs. with DKA) & $0.229(0.07-0.39)$ & 0.006 & $0.198(0.04-0.35)$ & 0.013 \\
\hline \multicolumn{5}{|l|}{ Body mass index category } \\
\hline Normal weight (vs. underweight) & $0.096(-0.08$ to 0.27$)$ & 0.284 & $0.123(-0.07$ to 0.32$)$ & 0.212 \\
\hline Overweight or obese (vs. underweight) & $0.252(0.01-0.50)$ & 0.044 & $0.290(0.04-0.54)$ & 0.022 \\
\hline Body mass index z-score & $0.040(-0.03$ to 0.11$)$ & 0.234 & - & - \\
\hline Male (vs. female) & $0.026(-0.12$ to 0.17$)$ & 0.729 & - & - \\
\hline Birth weight & $0.039(-0.10$ to 0.18$)$ & 0.586 & - & - \\
\hline $\mathrm{HbA} 1 \mathrm{c}$ & $-0.029(-0.06$ to 0.01$)$ & 0.092 & - & - \\
\hline
\end{tabular}

$\mathrm{Cl}$, Confidence interval; DKA, diabetic ketoacidosis; HbA1c, glycosylated hemoglobin.

Table 5. Factors associated with the preservation of C-peptide levels ( $\geq 0.6 \mathrm{ng} / \mathrm{mL}$ ) at diagnosis

\begin{tabular}{|c|c|c|c|c|}
\hline \multirow{2}{*}{ Factor } & \multicolumn{2}{|c|}{ Unadjusted } & \multicolumn{2}{|c|}{ Adjusted } \\
\hline & Odds ratio $(95 \% \mathrm{Cl})$ & $P$-value & Odds ratio $(95 \% \mathrm{Cl})$ & $P$-value \\
\hline Age at diagnosis (yr) & $1.207(1.10-1.32)$ & $<0.001$ & $1.217(1.09-1.36)$ & 0.001 \\
\hline Pubertal onset of diabetes (vs. prepubertal) & $4.137(2.00-8.54)$ & $<0.001$ & - & - \\
\hline Presentation without DKA (vs. with DKA) & $2.965(1.30-6.77)$ & 0.010 & $3.116(1.24-7.82)$ & 0.015 \\
\hline \multicolumn{5}{|l|}{ Body mass index category } \\
\hline Normal weight (vs. underweight) & $1.440(0.60-3.44)$ & 0.412 & $1.884(0.53-6.65)$ & 0.325 \\
\hline Overweight or obese (vs. underweight) & $3.429(1.03-11.41)$ & 0.045 & $5.012(1.06-23.71)$ & 0.042 \\
\hline Body mass index z-score & $1.252(0.91-1.72)$ & 0.163 & - & - \\
\hline Male (vs. female) & $1.065(0.54-2.12)$ & 0.857 & - & - \\
\hline Birth weight & $1.015(0.51-2.03)$ & 0.967 & - & - \\
\hline $\mathrm{HbA1c}$ & $0.925(0.79-1.09)$ & 0.340 & - & - \\
\hline
\end{tabular}

$\mathrm{Cl}$, Confidence interval; DKA, diabetic ketoacidosis; HbA1c, glycosylated hemoglobin. 
associated with insulin resistance ${ }^{16)}$. The interactions between hyperglycemia and the Fas receptor of beta cells, which trigger apoptosis (glucotoxicity) ${ }^{17)}$ and ectopic fat deposition in islets (lipotoxicity) ${ }^{18)}$, accelerate beta-cell apoptosis when insulin resistance is at play ${ }^{16)}$.

Whether insulin resistance accelerates either progression of insulin deficiency or the timing or onset of T1DM presentation remains controversial. We did not find that heavier children developed diabetes at younger ages. As overweight and obese children tended to have residual C-peptide at diagnosis, we adjusted C-peptide levels in an effort to find an independent relationship between BMI and age at onset. No such relationship was found regardless of adjustment for residual beta-cell function. Some previous studies ${ }^{19-22)}$, but not all, found that heavier children developed diabetes at earlier ages. However, we did not find this relationship, as in some other previous studies ${ }^{15,23)}$.

C-peptide levels correlated positively with age at diagnosis and were higher in pubertal than prepubertal children. The older the child, the higher the C-peptide level, consistent with previous studies ${ }^{13,23,24)}$. Puberty affects beta-cell failure; the pubertal growth spurt not only aggravates insulin resistance as a result of increased growth hormone but also increases insulin demand, leading to beta-cell overload and failure. Although the extent of residual beta-cell function was similar, pubertal children were more likely to develop hyperglycemia and diabetes than were prepubertal children.

As expected, C-peptide preservation was associated with presentation in the absence of DKA. Insulin deficiency is a major cause of DKA but, conversely, the metabolic effects of ketoacidosis may temporarily further reduce the ability to secrete insulin ${ }^{13)}$. Thus, children who presented with DKA had significantly lower levels of C-peptide at diagnosis.

Our study had several limitations. The levels of three or more diabetes-related autoantibodies were not measured in all patients at diagnosis. Only BMI was used to assess adiposity. Any difference in the honeymoon phase, or beta-cell loss with preservation of C-peptide levels, could not be evaluated, because daily insulin doses were not recorded reliably, and C-peptide levels were not measured during follow-up. As this retrospective study did not include the measurement of insulin resistance using glucose clamp technique ${ }^{25}$, the effect of insulin resistance on onset age of T1DM could not be analyzed.

In conclusion, overweight or obese children had slightly more residual beta-cell function at diagnosis than did underweight children. However, we found no evidence that obesity accelerates the timing of T1DM presentation. Further studies should evaluate whether BMI influences progression of beta-cell loss after T1DM onset. Strategies minimizing the loss of residual beta-cell mass in overweight or obese children are required.

\section{Conflict of interest}

No potential conflict of interest relevant to this article was reported.

\section{References}

1. Donath MY, Halban PA. Decreased beta-cell mass in diabetes: significance, mechanisms and therapeutic implications. Diabetologia 2004;47:581-9.

2. Libman IM, Becker DJ. Coexistence of type 1 and type 2 diabetes mellitus: "double" diabetes? Pediatr Diabetes 2003;4:110-3.

3. Dahlquist G. Can we slow the rising incidence of childhood-onset autoimmune diabetes? The overload hypothesis. Diabetologia 2006;49:20-4.

4. Naik RG, Brooks-Worrell BM, Palmer JP. Latent autoimmune diabetes in adults. J Clin Endocrinol Metab 2009;94: 4635-44.

5. Wilkin TJ. Is autoimmunity or insulin resistance the primary driver of type 1 diabetes? Curr Diab Rep 2013;13:6516.

6. Wilkin TJ. Diabetes: 1 and 2, or one and the same? Progress with the accelerator hypothesis. Pediatr Diabetes 2008;9(3 Pt 2):23-32.

7. Moon JS, Lee SY, Nam CM, Choi JM, Choe BK, Seo JW, et al. 2007 Korean National Growth Charts: review of developmental process and an outlook. Korean J Pediatr 2008;51:125.

8. Mei Z, Grummer-Strawn LM, Pietrobelli A, Goulding A, Goran MI, Dietz WH. Validity of body mass index compared with other body-composition screening indexes for the assessment of body fatness in children and adolescents. Am J Clin Nutr 2002;75:978-85.

9. Palmer JP, Fleming GA, Greenbaum CJ, Herold KC, Jansa $\mathrm{LD}, \mathrm{Kolb} \mathrm{H}$, et al. C-peptide is the appropriate outcome measure for type 1 diabetes clinical trials to preserve betacell function: report of an ADA workshop, 21-22 October 2001. Diabetes 2004;53:250-64.

10. Effects of age, duration and treatment of insulin-dependent diabetes mellitus on residual beta-cell function: observations during eligibility testing for the Diabetes Control and Complications Trial (DCCT). The DCCT Research Group. J Clin Endocrinol Metab 1987;65:30-6.

11. Effect of intensive therapy on residual beta-cell function in patients with type 1 diabetes in the diabetes control and complications trial. A randomized, controlled trial. The Diabetes Control and Complications Trial Research Group. Ann Intern Med 1998;128:517-23.

12. Steffes MW, Sibley S, Jackson M, Thomas W. Beta-cell function and the development of diabetes-related complications in the diabetes control and complications trial. Diabetes Care 2003;26:832-6.

13. Redondo MJ, Rodriguez LM, Escalante M, O'Brian Smith E, Balasubramanyam A, Haymond MW. Beta cell function and BMI in ethnically diverse children with newly diagnosed autoimmune type 1 diabetes. Pediatr Diabetes 2012;13:564-71.

14. Ludvigsson J, Carlsson A, Deli A, Forsander G, Ivarsson SA, Kockum I, et al. Decline of C-peptide during the first 
year after diagnosis of Type 1 diabetes in children and adolescents. Diabetes Res Clin Pract 2013;100:203-9.

15. Cedillo M, Libman IM, Arena VC, Zhou L, Trucco M, Ize-Ludlow D, et al. Obesity, islet cell autoimmunity, and cardiovascular risk factors in youth at onset of type 1 autoimmune diabetes. J Clin Endocrinol Metab 2015;100:E826.

16. Wilkin TJ. The convergence of type 1 and type 2 diabetes in childhood: the accelerator hypothesis. Pediatr Diabetes 2012;13:334-9.

17. Maedler K, Spinas GA, Lehmann R, Sergeev P, Weber M, Fontana A, et al. Glucose induces beta-cell apoptosis via upregulation of the Fas receptor in human islets. Diabetes 2001;50:1683-90.

18. Frayn KN. Adipose tissue as a buffer for daily lipid flux. Diabetologia 2002;45:1201-10.

19. Kibirige M, Metcalf B, Renuka R, Wilkin TJ. Testing the accelerator hypothesis: the relationship between body mass and age at diagnosis of type 1 diabetes. Diabetes Care 2003;26:2865-70.

20. Betts P, Mulligan J, Ward P, Smith B, Wilkin T. Increasing body weight predicts the earlier onset of insulin-dependant diabetes in childhood: testing the 'accelerator hypothesis'
(2). Diabet Med 2005;22:144-51.

21. Knerr I, Wolf J, Reinehr T, Stachow R, Grabert M, Schober $\mathrm{E}$, et al. The 'accelerator hypothesis': relationship between weight, height, body mass index and age at diagnosis in a large cohort of 9,248 German and Austrian children with type 1 diabetes mellitus. Diabetologia 2005;48:2501-4.

22. Dabelea D, D'Agostino RB Jr, Mayer-Davis EJ, Pettitt DJ, Imperatore G, Dolan LM, et al. Testing the accelerator hypothesis: body size, beta-cell function, and age at onset of type 1 (autoimmune) diabetes. Diabetes Care 2006;29:2904.

23. Greenbaum CJ, Anderson AM, Dolan LM, Mayer-Davis EJ, Dabelea D, Imperatore G, et al. Preservation of betacell function in autoantibody-positive youth with diabetes. Diabetes Care 2009;32:1839-44.

24. Sochett EB, Daneman D, Clarson C, Ehrlich RM. Factors affecting and patterns of residual insulin secretion during the first year of type 1 (insulin-dependent) diabetes mellitus in children. Diabetologia 1987;30:453-9.

25. Donga E, Dekkers OM, Corssmit EP, Romijn JA. Insulin resistance in patients with type 1 diabetes assessed by glucose clamp studies: systematic review and meta-analysis. Eur J Endocrinol 2015;173:101-9. 